\title{
Compatibility between entomopathogenic nematodes and crop protection products used in maize seed treatment
}

\section{Compatibilidade entre nematoides entomopatogênicos e produtos fitossanitários utilizados no tratamento de sementes de milho}

\author{
Maria Eduarda Berlatto Magnabosco ${ }^{1 *}$; Vanessa Andaló ${ }^{2}$; Lucas Silva de Faria ${ }^{3}$
}

\begin{abstract}
Chemical insecticides are widely used to control soil pests but not always effective. Entomopathogenic nematodes (NEPs) are found in the soil and depend on host insects to complete their life cycle, and therefore have the potential to control soil pests. Thus, we aimed to investigate the possible joint use of these control methods by assessing the compatibility of two nematodes (Heterorhabditis amazonensis GL and Heterorhabditis amazonensis MC01) with five crop protection products used for maize seed treatment $\left(\right.$ Maxim $^{\circledR}$, Cruiser $350 \mathrm{FS}^{\circledR}$, Fortenza $600 \mathrm{FS}^{\circledR}$, Avicta $500 \mathrm{FS}^{\circledR}$, and Amulet ${ }^{\circledR}$ ), as well as one neem-based product $\left(\mathrm{NeenMax}^{\circledR}\right)$. The experimental design was completely randomized with five replicates, six treatments, and one control, in which only distilled water was added to nematode suspension. Each replicate consisted of a test tube containing $1 \mathrm{~mL}$ suspension with 2,000 infective juveniles (IJs) and $1 \mathrm{~mL}$ of diluted product, following the manufacturer's recommendation. The evaluated parameters were viability, infectivity on Tenebrio molitor larvae and IJs production after exposure to products. Both nematodes were compatible with NeenMax ${ }^{\circledR}$ and Fortenza $600 \mathrm{FS}^{\circledR}$ since they did not differ from the control and were classified as innocuous. Cruiser $350 \mathrm{FS}{ }^{\circledR}$ was also compatible with the nematodes since the effect value of the product was lower than $30 \%$. Amulet ${ }^{\circledR}$ was classified as slightly noxious, reducing $H$. amazonensis MC01 and $H$. amazonensis GL infectivity by $17.5 \%$ and $28.5 \%$, and production by $18.2 \%$ and $22.3 \%$, respectively. Despite not having reduced viability, Avicta $500 \mathrm{FS}^{\circledR}$ and Maxim $^{\circledR}$ were considered harmful. This is because Avicta $500 \mathrm{FS}^{\circledR}$ and Maxim ${ }^{\circledR}$ reduced productivity by $70.0 \%$ and $72.5 \%$ and production by $66.1 \%$ and $65.4 \%$ for $H$. amazonensis $\mathrm{MC} 01$, respectively. For $H$. amazonensis $\mathrm{MC} 01$, both Avicta $500 \mathrm{FS}^{\circledR}$ and Maxim ${ }^{\circledR}$ reduced infectivity by $76.19 \%$, and production by $63.7 \%$ and $62.3 \%$, respectively.
\end{abstract}

Key words: Biological control. Cornstalk borer. Heterorhabditis. Integrated pest management. Seed treatment.

\section{Resumo}

\begin{abstract}
Os inseticidas químicos apesar de serem os mais utilizados para controle de pragas de solo, nem sempre são eficazes. Os nematoides entomopatogênicos (NEPs) são encontrados no solo e utilizam insetos como hospedeiros para completarem seu ciclo de vida, assim, apresentam potencial no controle de pragas com hábito subterrâneo. Com isso, destaca-se a importância de se avaliar a possibilidade de uso conjunto desses métodos de controle, objetivando-se avaliar a compatibilidade dos nematoides Heterorhabditis amazonensis GL e Heterorhabditis amazonensis MC01 com cinco produtos fitossanitários utilizados no tratamento de sementes de milho, Maxim ${ }^{\circledR}$, Cruiser $350 \mathrm{FS}^{\circledR}$, Fortenza $600 \mathrm{FS}^{\circledR}$, Avicta $500 \mathrm{FS}^{\circledR}$

\footnotetext{
Discente, Universidade Federal de Uberlândia, UFU, Uberlândia, MG, Brasil. E-mail: dudamagnabosco@hotmail.com

2 Profa, Uberlândia, UFU, Monte Carmelo, MG, Brasil. E-mail: vanessaandalo@ufu.br

3 Pesquisador, UFU, Monte Carmelo, MG, Brasil. E-mail: lucassilvafaria@hotmail.com

Author for correspondence
} 
e Amulet ${ }^{\circledR}$, além de um produto à base de nim, NeenMax ${ }^{\circledR}$. O ensaio foi conduzido em delineamento inteiramente casualizado com cinco repetições, totalizando seis tratamentos e o controle, no qual foi adicionada apenas água destilada à suspensão do nematoide. Cada repetição foi constituída de um tubo de ensaio contendo $1 \mathrm{~mL}$ de suspensão com 2.000 juvenis infectantes (JIs) e $1 \mathrm{~mL}$ do produto diluído de acordo com a recomendação do fabricante. Foram avaliados os parâmetros viabilidade, infectividade sobre larvas de Tenebrio molitor e produção de JIs após o contato com os produtos. Verificou-se que para ambos os nematoides os produtos NeenMax ${ }^{\circledR}$ e Fortenza $600 \mathrm{FS}^{\circledR}$ foram considerados compatíveis, pois não diferiram do controle e foram classificados como inócuos. O produto Cruiser $350 \mathrm{FS}^{\circledR}$ também foi compatível aos nematoides testados, já que o valor de efeito do produto obtido foi menor que $30 \%$. O produto Amulet ${ }^{\circledR}$ foi classificado como levemente nocivo, causando uma redução de $17,5 \%$ na infectividade e de $18,2 \%$ na produção de $H$. amazonensis MC01 e de $28,5 \%$ e $22,3 \%$ para $H$. amazonensis GL. Avicta $500 \mathrm{FS}^{\circledR}$ e Maxim ${ }^{\circledR}$ foram considerados nocivos, pois apesar de não reduzirem a viabilidade dos nematoides, diminuíram em $70,0 \%$ e $72,5 \%$ a infectividade e $66,1 \%$ e $65,4 \%$ a produção de $H$. amazonensis MC01, respectivamente; enquanto para $H$. amazonensis GL causaram o mesmo valor de redução de infectividade, $76,19 \%$, e causaram $63,7 \%$ e $62,3 \%$ de redução da produção, respectivamente.

Palavras-chave: Broca-do-colmo. Controle biológico. Heterorhabditis. Manejo integrado de pragas. Tratamento de sementes.

\section{Introduction}

Maize production chain is an important pillar of the Brazilian agribusiness, corresponding to approximately $40 \%$ of the national grain production (CONAB, 2018). Both international demand and domestic consumption of maize have increased in recent years, because of its use for livestock feed production and due to the growth of the meat market, mainly poultry and pork (PAVÃO; FERREIRA FILHO, 2011).

Despite the large area under maize cultivation in Brazil, crop yields are among the lowest worldwide, on account of several factors that may contribute to such low productivities (CONAB, 2018; USDA, 2019). One of these factors is a large number of difficult-to-manage insect pests damaging the crop, such as Elasmopalpus lignosellus (Zeller) (Lepidoptera: Pyralidae), which is found near or inside maize stems or even lodged into the soil, becoming a hard target for chemical applications (ZORZETTI et al., 2017).

Data on damage by soil insect pests are scarce, but it is estimated that damages by E. lignosellus may increase losses in more than $20 \%$ to total crop destruction when under high infestation levels (VIANA, 2004). Such infestation index (20\%) in seedlings may correspond to reductions of 2.8 and $2.4 \%$ in grain and silage productions, respectively (ALL et al., 1982).

Pest control strategies in maize crops are based on the use of insecticides. Seed treatment is the most used chemical control due to practicality, cost, and efficiency. However, in areas with severe drought records and consequently low soil moisture, insecticides show reduced effectiveness. This happens because insecticides require moisture to provide effective caterpillar control, and besides that, dry soils are favorable to a lesser cornstalk borer development (VIANA; MENDES, 2011).

The inappropriate use of chemical control methods tends to select resistant insect populations, causing harmful effects to the environment, animal health, and high production costs (DALVI et al., 2011; ZORZETTI et al., 2017). Thus, it is necessary to develop alternative control methods such as biological control.

Entomopathogenic nematodes (EPNs) of the families Steinernematidae and Heterorhabditidae (Nematoda: Rhabditida) have the potential to be used as biological control agents, due to their capability to develop an intimate and specific association with bacteria responsible for disease establishment and 
consequently insect death (NGUYEN; HUNT, Material and Methods 2007).

Studies have demonstrated that NEPs are effective in controlling pests of different crops (FOELKEL et al., 2016; GIOMETTI et al., 2011; MANACHINI et al., 2013). Feaster and Steinkraus (1996) and Andaló et al. (2010) assessed pupae control of Helicoverpa zea (Boddie) (Lepidoptera: Noctuidae) and Spodoptera frugiperda (Smith) (Lepidoptera: Noctuidae) in maize using NEPs; both pests had mortality rates higher than $90 \%$. Lepidoptera, such as E. lignosellus, pupate in the soil and become reachable targets for NEPs, which are found in the soils of several biomes worldwide, completing their life cycle hosting in insects (LAWRENCE et al., 2006).

The aim of this study was to assess the compatibility of crop protection products recommended for maize seed treatment and a neem-based insecticide with two entomopathogenic nematodes, Heterorhabditis amazonensis GL and H. amazonensis MC01.
The nematodes used in the experiments were cultured in larvae of Tenebrio molitor L. (Coleoptera: Tenebrionidae), reared according to the method of Potrich et al. (2007) and collected according to the method of Molina and López (2001).

Five crop protection products recommended for maize seed treatment $\left(\right.$ Maxim $^{\circledR}$, Cruiser 350 FS $^{\circledR}$, Fortenza $600 \mathrm{FS}^{\circledR}$, Avicta $500 \mathrm{FS}^{\circledR}$, and Amulet ${ }^{\circledR}$ ) and one neem-based insecticide $\left(\mathrm{NeenMax}^{\circledR}\right)$ were tested for compatibility with two entomopathogenic nematodes (H. amazonensis GL and H. amazonensis MC01). There were, therefore, a total of six treatments (products) plus one control treatment (distilled water). Each treatment had five replicates.

The experiment was conducted following the IOBC/WPRS protocol, proposed by Vainio (1992). Working solutions were prepared for each product (Table 1), using double the dose recommended by the manufacturer per water $\mathrm{mL}$. Thus, the used volumes were $0.31 \mathrm{~mL}$ of Maxim $^{\circledR}, 0.60 \mathrm{~mL}$ of Cruiser $350 \mathrm{FS}^{\circledR}, 0.87 \mathrm{~mL}$ of Fortenza $600 \mathrm{FS}^{\circledR}, 0.15$ $\mathrm{mL}$ of Avicta $500 \mathrm{FS}^{\circledR}, 0.5 \mathrm{~mL}$ of Amulet ${ }^{\circledR}$, and 0.25 $\mathrm{mL}$ of NeenMax ${ }^{\circledR}$.

Table 1. Phytosanitary products used in the compatibility study with entomopatogenic nematodes (AGROFIT, 2018).

\begin{tabular}{|c|c|c|c|}
\hline Trademark & Active ingredient & Description & Dose \\
\hline $\operatorname{Maxim}^{\circledR}$ & $\begin{array}{l}\text { Fludioxonil } 25 \mathrm{~g} \mathrm{~L}^{-1} \\
\text { Inert ingredients } 1018 \mathrm{~g} \mathrm{~L}^{-1}\end{array}$ & Fungicide & $150 \mathrm{~mL} \mathrm{cp} * / 100 \mathrm{~kg}$ seeds \\
\hline Cruiser $350 \mathrm{FS}^{\circledR}$ & $\begin{array}{l}\text { Thiametoxam } 350 \mathrm{~g} \mathrm{~L}^{-1} \text {; } \\
\text { Other ingredients } 820 \mathrm{~g} \mathrm{~L}^{-1}\end{array}$ & Insecticide & $120 \mathrm{~mL} / 60.000$ seeds \\
\hline Fortenza $600 \mathrm{FS}^{\circledR}$ & $\begin{array}{l}\text { Cyantraniliprole } 600 \mathrm{~g} \mathrm{~L}^{-1} \text {; } \\
\text { Other Ingredients } 630 \mathrm{~g} \mathrm{~L}^{-1}\end{array}$ & Insecticide & $350 \mathrm{~mL} / 100 \mathrm{~kg}$ seeds \\
\hline Avicta $500 \mathrm{FS}^{\circledR}$ & $\begin{array}{l}\text { Abamectin } 500 \mathrm{~g} \mathrm{~L}^{-1} \\
\text { Other ingredients } 508 \mathrm{~g} \mathrm{~L}^{-1}\end{array}$ & Nematicide e Insecticide & $60-70 \mathrm{~mL} / 60.000$ seeds \\
\hline Amulet $^{\circledR}$ & $\begin{array}{c}\text { Fipronil } 250 \mathrm{~g} \mathrm{~L}^{-} 1 \\
\text { Other ingredients } 850 \mathrm{~g} \mathrm{~L}^{-1}\end{array}$ & Insecticide & $50-200 \mathrm{~mL} \mathrm{ha}^{-1}$ \\
\hline NeenMax ${ }^{\circledR}$ & $\begin{array}{c}\text { Azadirachtin }(1,200 \mathrm{ppm}) 1.0 \% \text {; } \\
\text { Inerts } 99.0 \%\end{array}$ & Insecticide & $200 \mathrm{~mL} \mathrm{~L}^{-1}$ of water \\
\hline
\end{tabular}

*Commercial product. 
An aliquot of $1 \mathrm{~mL}$ of each working solution was placed into a glass tube $(8 \mathrm{~cm}$ high $\times 2.5 \mathrm{~cm}$ in diameter), together with $1 \mathrm{~mL}$ of distilled water containing 2,000 infective juveniles (IJs). Thus, each tube contained a total volume of $2 \mathrm{~mL}(1 \mathrm{~mL}$ of product $+1 \mathrm{~mL}$ of EPN suspension). For the control, $1 \mathrm{~mL}$ of distilled water was added to $1 \mathrm{~mL}$ of the EPN suspension. The tubes were sealed with Parafilm ${ }^{\circledR}$ and kept in a chamber under the following controlled conditions: $24 \pm 1{ }^{\circ} \mathrm{C}$ temperature, $70 \pm$ $10 \%$ relative humidity, and scotophase.

The assessed parameters were viability, infectivity, and IJs production after exposure to products. Due to the strong pigmentation of products, the JIs cleaning preceded the viability evaluation. Cleaning was done by passing the nematode suspensions through a 500-mesh sieve, using water for washing the IJs, which were retained without the products. Afterward, the initial volume of $2 \mathrm{~mL}$ was adjusted by adding distilled water. This procedure was carried out for all treatments in order to standardize the method for all tested products.

Viability assessment was done after $48 \mathrm{~h}$, removing $0.1 \mathrm{~mL}$ of suspension from each tube, observing the IJs under a stereo microscope and counting the total number of live and dead juveniles in the aliquot. Those that remained inert, following the addition of $50 \mu \mathrm{L}$ of $\mathrm{NaOH}$, were considered dead (CHEN; DICKSON, 2000).

Juvenile infectivity was assessed by adding 3 $\mathrm{mL}$ of distilled water into the tubes, which were left for 30 minutes in the refrigerator $\left(10^{\circ} \mathrm{C}\right)$ for IJs decantation. After this period, supernatant (about 3 $\mathrm{mL}$ ) was discarded. This washing procedure was repeated three times.

Once the washing was completed, $1.0 \mathrm{~mL}$ was withdrawn from the bottom of each replicate (each tube) and placed in a glass Petri dish $(9 \mathrm{~cm}$ in diameter) containing two filter paper sheets and ten T. molitor larvae. The Petri dishes were kept for five days in a chamber, under the same conditions previously described. After this period, the percentage of larvae killed by the nematodes was determined by counting the number reddishbrown larvae, which is characteristic death symptomatology caused by Heterorhabditis (KAYA et al., 1993).

To determine IJs production, the larvae killed by nematodes during the infectivity test were transferred to White's traps and kept in a chamber under the aforementioned conditions. The IJs produced were collected from the White's traps for five days and counted under a stereo microscope.

Normality and homoscedasticity assumptions were tested by the Shapiro-Wilk and Levene's tests, respectively. Subsequently, the IJs viability and insect mortality data were submitted to analysis of variance, and nematode mortality values were corrected by the Abbott (1925) formula:

$$
M c \%=\frac{M o \%-M t \% \times 100}{100-M t \%}
$$

$\mathrm{Mc}=$ Corrected mortality; $\mathrm{Mo}=$ Observed mortality; and $\mathrm{Mt}=$ Control mortality .

Infectivity was obtained from T. molitor larvae mortality percentage. The infectivity reduction caused by the treatments was determined by the formula:

$$
\operatorname{Rinf} \%=\left(1-\frac{I t \%}{I c \%}\right) \times 100
$$

Rinf $\%=$ Infectivity reduction; It $\%=$ Treatment infectivity; and Ic $\%=$ Control infectivity.

Production was determined by counting the number of IJs obtained from T. molitor larvae. The production reduction caused by the treatments was determined by the formula:

$$
R f e c \%=\left(1-\frac{F t}{F C}\right) \times 100
$$

$\mathrm{Rfec} \%=$ Production reduction; $\mathrm{Ft}=$ Treatment production; and $\mathrm{Fc}=$ Control production . 
The Peters and Poullot (2004) modified formula was used in order to determine the insecticide effect (E\%).

$E \%=100-(100-M \operatorname{corr} \%-\operatorname{Rinf} \%-\operatorname{Rfec} \%)$

The aforementioned formula follows the IOBC standards (International Organization for Biological and Integrated Control of Noxious Animals and Plants). For E\% calculation, a zero (0) was assigned to the factors $\mathrm{Mc} \%$, Rinf $\%$, and $\mathrm{Rfec} \%$, when they presented negative values.
The effect values of insecticides were classified as: innocuous $(\mathrm{E} \%<30)$, slightly noxious $(\mathrm{E} \%$ entre 30 a 79), moderately noxious ( $\mathrm{E} \%$ entre 80 a $99)$ and noxious $(\mathrm{E} \%>99)$.

\section{Results and Discussion}

Regarding viability, the survival of IJs exceeded $95 \%$ for most of the products. The highest mortality for both nematodes was caused by Maxim $\AA$, with $7.63 \%$ for $H$. amazonensis $\mathrm{MC} 01$ and $7.21 \%$ for $H$. amazonensis GL (Tables 2 and 3).

Table 2. Compatibility of Heterorhabditis amazonensis MC01 after 48 hours of exposure to phytosanitary products (protocol IOBC/WPRS), Vainio (1992).

\begin{tabular}{lccccccc}
\hline \multicolumn{1}{c}{ Treatment } & Viability (\%) & Infectivity (\%) & Mc\% & Rinf\% & Rfec\% & E\% & IOBC Classificarion \\
\hline Control & $99.6 \pm 0.55 \mathrm{a}$ & $80.0 \pm 7.07 \mathrm{~b}$ & 0.0 & 0.0 & 0.0 & 0.0 & Innocuous \\
NeenMax $^{\circledR}$ & $99.2 \pm 1.10 \mathrm{a}$ & $88.0 \pm 8.37 \mathrm{a}$ & 0.40 & 0.0 & 0.0 & 0.0 & Innocuous \\
${\text { Fortenza } 600 \mathrm{FS}^{\circledR}} 99.0 \pm 1.22 \mathrm{a}$ & $96.0 \pm 5.48 \mathrm{a}$ & 0.60 & 0.0 & 0.0 & 0.0 & Innocuous \\
Cruiser 350 FS $^{\circledR}$ & $97.0 \pm 2.00 \mathrm{~b}$ & $70.0 \pm 7.07 \mathrm{c}$ & 2.61 & 12.50 & 0.0 & 13.50 & Innocuous \\
Avicta 500 FS & $96.8 \pm 0.84 \mathrm{~b}$ & $24.0 \pm 5.48 \mathrm{~d}$ & 2.81 & 70.00 & 66.1 & 138.89 & Harmful \\
Amulet $^{\circledR}$ & $95.6 \pm 3.29 \mathrm{~b}$ & $66.0 \pm 8.94 \mathrm{c}$ & 4.02 & 17.50 & 18.2 & 39.68 & Slightly harmful \\
Maxim $^{\circledR}$ & $92.0 \pm 1.58 \mathrm{c}$ & $22.0 \pm 8.37 \mathrm{~d}$ & 7.63 & 72.50 & 65.4 & 145.56 & Harmful \\
\hline $\mathrm{CV}(\%)$ & 1.79 & 11.56 & & & & & \\
\hline
\end{tabular}

Means followed by the same letter are not significantly different $(\mathrm{P}<0.05)$.

Mean \pm Standard Error

$\mathrm{Mc} \%=$ Corrected mortality

Rinf $\%=$ Infectivity reduction

$\mathrm{Rfec} \%=$ Production reduction

$\mathrm{E} \%=$ Insecticide effect.

The viability for both nematodes did not differ after exposure to Cruiser $350 \mathrm{FS}^{\circledR}$, Avicta $500 \mathrm{FS}^{\circledR}$, and Amulet ${ }^{\circledR}$. When exposed to Cruiser $350 \mathrm{FS}^{\circledR}$ and Avicta $500 \mathrm{FS}^{\circledR}$, the IJs of $H$. amazonensis $\mathrm{MC} 01$ and of $H$. amazonensis GL had mortality rates of $2.61 \%$ and $2.81 \%$, respectively. Yet, when exposed to Amulet ${ }^{\circledR}, H$. amazonensis $\mathrm{MC} 01$ had its viability reduced by $4.02 \%$ and $H$. amazonensis GL by $3.01 \%$. On the other hand, NeenMax ${ }^{\circledR}$ and Fortenza $600 \mathrm{FS}^{\circledR}$ did not differ from the control in terms of viability (Tables 2 and 3 ).
The infectivity of $H$. amazonensis MC01 to $T$. molitor larvae increased after exposure to NeenMax ${ }^{\circledR}$ and Fortenza $600 \mathrm{FS}^{\circledR}$ when compared to the control (Table 2). Similarly, Abdel-Rasek and Gowen (2002) and Mahmoud (2007) also showed the compatibility of nematodes of the genus Heterorhabditis with neem extract, indicating that the combined use of the nematode and neem may lead to a synergistic effect on the control of Plutella xylostella L. (Lepidoptera: Plutellidae) and Bactrocera zonata (Saunders) (Diptera: Tephritidae). 
Table 3. Compatibility of Heterorhabditis amazonensis GL after 48 hours of exposure to phytosanitary products (protocol IOBC/WPRS). Vainio (1992).

\begin{tabular}{lccccccc}
\hline \multicolumn{1}{c}{ Treatment } & Viability (\%) & Infectivity (\%) & Mc\% & Rinf\% & Rfec\% & E\% & IOBC Classification \\
\hline Control & $99.8 \pm 0.45 \mathrm{a}$ & $84.0 \pm 5.48 \mathrm{a}$ & 0.0 & 0.0 & 0.0 & 0.0 & Innocuous \\
NeenMax $^{\circledR}$ & $99.6 \pm 0.55 \mathrm{a}$ & $82.0 \pm 8.37 \mathrm{a}$ & 0.20 & 2.38 & 3.7 & 6.32 & Innocuous \\
Fortenza 600 FS $^{\circledR}$ & $98.6 \pm 1.34 \mathrm{a}$ & $86.0 \pm 5.48 \mathrm{a}$ & 1.20 & 0.0 & 6.9 & 5.7 & Innocuous \\
Cruiser 350 FS $^{\circledR}$ & $97.2 \pm 0.84 \mathrm{~b}$ & $76.0 \pm 5.48 \mathrm{a}$ & 2.61 & 9.52 & 2.8 & 14.97 & Innocuous \\
Avicta 500 FS $^{\circledR}$ & $97 \pm 1.58 \mathrm{~b}$ & $20.0 \pm 7.07 \mathrm{c}$ & 2.81 & 76.19 & 63.7 & 142.67 & Harmful \\
Amulet $^{\circledR}$ & $96.8 \pm 0.84 \mathrm{~b}$ & $60.0 \pm 7.07 \mathrm{~b}$ & 3.01 & 28.57 & 22.3 & 53.85 & Slightly harmful \\
Maxim $^{\circledR}$ & $92.6 \pm 1.52 \mathrm{c}$ & $20.0 \pm 7.07 \mathrm{c}$ & 7.21 & 76.19 & 62.3 & 145.74 & Harmful \\
\hline CV (\%) & 1.13 & 10.88 & & & & & \\
\hline
\end{tabular}

Means followed by the same letter are not significantly different $(\mathrm{P}<0.05)$.

Mean \pm Standard Error

$\mathrm{Mc} \%=$ Corrected mortality

Rinf $\%=$ Infectivity reduction

$\mathrm{Rfec} \%=$ Production reduction

$\mathrm{E} \%=$ Insecticide effect.

Cruiser $350 \mathrm{FS}^{\circledR}(12.5 \%)$ and Amulet $^{\circledR}(17.5 \%)$ reduced $H$. amazonensis $\mathrm{MC} 01$ infectivity, which did not differ from each other (Table 2). Despite that, Cruiser $350 \mathrm{FS}^{\circledR}$ was classified as innocuous while Amulet $^{\circledR}$ as slightly noxious. Such a difference may be because the IOBC protocol takes into account all the analyzed parameters for the classification of products (E\%) (Table 2).

Tavares et al. (2009) exposed the nematodes $H$. indica IBCBn5 and Steinernema brasilense IBCBn6 to thiamethoxam, which is the active ingredient in Cruiser $350 \mathrm{FS}^{\circledR}$, and demonstrated the compatibility of both nematodes with the insecticide. Other studies have already reported the compatibility of thiamethoxam with other nematode species, e.g., H. bacteriophora, S. carpocapsae, S. glaseri, and $S$. arenarium (KOPPENHÖFER; KAYA, 1998; KOPPENHÖFER et al., 2003; ALUMAI; GREWAL, 2004; ANDALÓ et al., 2004).

Maxim $^{\circledR}$ and Avicta 500 FS $^{\circledR}$ caused similar effects on both nematodes, reducing both infectivity and production of the IJs. Maxim ${ }^{\circledR}$ reduced infectivity and production by $72.5 \%$ and $65.4 \%$ for H. amazonensis MC01 and by $76.19 \%$ and $62.3 \%$ for $H$. amazonensis GL, respectively. Avicta $500 \mathrm{FS}^{\circledR}$ reduced infectivity and production by $70.0 \%$ and $66.1 \%$ for $H$. amazonensis MC01 and by $76.19 \%$ and $63.7 \%$ for $H$. amazonensis GL respectively. Thus, Maxim ${ }^{\circledR}$ and Avicta 500 FS $^{\circledR}$ were considered incompatible with both nematodes after exposure for 48 hours (Tables 2 and 3).

When exposed to Amulet ${ }^{\circledR}, H$. amazonensis MC01 reduced its infectivity by $17.5 \%$ and production by $18.2 \%$, while $H$. amazonensis GL exposure to Amulet ${ }^{\circledR}$ reduced its infectivity by $28.57 \%$ and production by $22.3 \%$. Therefore, Amulet ${ }^{\circledR}$ was considered to be slightly noxious to IJs according to the IOBC classification (Table 3).

Infectivity reduction may be related to the fact that some chemicals reduce the amount of lipids in nematodes, which are an important energy source for these organisms, as observed by Andaló et al. (2009) for H. amazonensis RSC5 when applied on caterpillars [Galleria mellonella (L.) (Lepidoptera: Pyralidae)] treated with the herbicides Ranger ${ }^{\circledR}$ and Topeze $^{\circledR}$, for 5 days.

Sabino et al. (2014) found similar results regarding infectivity reduction when the IJs of $H$. amazonensis JPM4 were exposed to abamectin, which is the active ingredient in Avicta $500 \mathrm{FS}^{\circledR}$. 
Likewise, such a reduction in infectivity was also associated with a decrease in lipid reserves.

In general, the products Cruiser $350 \mathrm{FS}^{\circledR}$, Fortenza $600 \mathrm{FS}^{\circledR}$, and NeenMax ${ }^{\circledR}$ were compatible with both nematodes. This is because the effect of the product (E\%) was lower than 30 (Tables 2 and 3), which shows the potential for the combined use of these products with the nematodes. Amulet ${ }^{\circledR}$, Avicta $500 \mathrm{FS}^{\circledR}$, and Maxim ${ }^{\circledR}$ were noxious since the E\% was higher than $30 \%$, indicating the noncompatibility of the products with the nematodes under the tested conditions.

Field tests are still needed to assess the effects of products considered to be harmful to nematodes because, under laboratory conditions, the EPNs are subjected to maximal insecticide exposure, whereas in the field there are other factors that may influence nematode responses.

\section{Conclusions}

According to the IOBC classification, Amulet ${ }^{\circledR}$ was classified as slightly noxious to $H$. amazonensis MC01 and $H$. amazonensis GL, while Avicta 500 FS $^{\circledR}$ and Maxim ${ }^{\circledR}$ were considered noxious, indicating that treating seeds with these products may interfere with nematode survival in the soil. NeenMax ${ }^{\circledR}$, Fortenza $600 \mathrm{FS}^{\circledR}$, and Cruiser $350 \mathrm{FS}^{\circledR}$ were considered innocuous to both nematodes.

\section{References}

ABBOTT, W. S. A method of computing the effectiveness of an insecticide. Journal of Economic Entomology, Oxford, v. 18, n. 1, p. 265-266, 1925. DOI: 10.1093/ jee/18.2.265a

ABDEL-RASEK, A. S.; GOWEN, S. The integrated effect to the nematode-bacteria complex and neem plant extracts against Plutella xylostella (L.) larvae (Lepidoptera: Yponomeutidae) on chinese cabbage. Archive Phytopathology and Plant Protection, Abingdon, v. 35, n. 3, p. 181-188, 2002. DOI: $10.1080 / 03235400215658$
AGROFIT. Sistemas de agrotóxicos fitossanitários. Brasil: Ministério da Agricultura, 2018. Disponível em: http://extranet.agricultura.gov.br/agrofit_cons/principal_ agrofit_cons. Acesso em: 20 out. 2018.

ALL, J. H.; GARDNER, W. A.; SUBER, E. F.; ROGERS, B. Lesser cornstalk borer as a pest of corn and sorghum. In: TIPPINS, H. H. (Ed.). A review of information on the lesser cornstalk borer Elasmopalpus lignosellus. Athens: University of Georgia, Special Publication, 1982. p. 3346.

ALUMAI, A.; GREWAL, P. S. Tank-mix compatibility of the entomopathogenic nematodes, Heterorhabditis bacteriophora and Steinernema carpocapsae, with selected chemical pesticides used in turfgrass. Biocontrol Science and Technology, Abingdon, v. 14, n. 7, p. 725730, 2004. DOI: 10.1080/09583150410001724334

ANDALÓ, V.; MOINO JUNIOR, A.; SANTACECÍLIA, L. V. C. Compatibilidade de nematoides entomopatogênicos com produtos fitossanitários utilizados na cultura do cafeeiro. Nematologia Brasileira, Campinas, v. 28, n. 1, p. 149-158, 2004.

ANDALÓ, V.; MOREIRA, G. F.; MAXIMINIANO, C.; MOINO JUNIOR, A.; CAMPOS, V. P. Influence of herbicides on lipid reserves, mortality and infectivity of Heterorhabditis amazonensis (Rhabditida: Heterorhabditidae). Nematologia Mediterranea, Florida, v. 37, n. 1, p. 11-15, 2009.

ANDALÓ, V.; SANTOS, V.; MOREIRA, G. F.; MOREIRA, C. C.; MOINO JUNIOR, A. Evaluation of entomopathogenic nematodes under laboratory and greenhouses conditions for the control of Spodoptera frugiperda. Ciência Rural, Santa Maria, v. 40, n. 9, p. 18601866, 2010. DOI: 10.1590/S0103-84782010005000151

CHEN, S. Y.; DICKSON, D. W. A technique for determining live second-stage juveniles of Heterodera glycines. Journal of Nematology, Florida, v. 32, n. 1, p. 117-121, 2000.

COMPANHIA NACIONAL DE ABASTECIMENTO - CONAB. Safras: séries históricas: séries históricas de área plantada, produtividade e produção, relativas às safras 1976/77 a 2015/16 de grãos, 2001 a 2016 de café, 2005/06 a 2016/17 de cana-de-açúcar. Brasília: Ministério da Agricultura, 2018. Disponível em: http:// www.conab.gov.br/info-agro/safras/serie-historica-dassafras?start=20. Acesso em: 10 jan. 2019.

DALVI, L. P.; ANDRADE, G. S.; PRATISSOLI, D.; POLANCZYK, R. A.; MELO, R. L. Compatibility of biological agents to control Spodoptera frugiperda (Lepidoptera: Noctuidae). Agrarian, Grande Dourados, v. 4, n. 12, p. 79-83, 2011. 
FEASTER, M. A.; STEINKRAUS, D. C. Inundative biological control of Helicoverpa zea (Lepidoptera: Noctuidae) with the entomopathogenic nematode Steinernema riobravis (Rhabditida: Steinernematidae). Biological Control, Amsterdã, v. 7, n. 1, p. 38-46, 1996. DOI: 10.1006/bcon.1996.0061

FOELKEL, E.; MONTEIRO, L. B.; VOSS, M. Virulence of nematodes against larvae of the south-American fruit fly in laboratory using soil from Porto Amazonas, Paraná, Brazil, as substrate. Ciência Rural, Santa Maria, v. 46, n. 3, p. 405-410, 2016. DOI: 10.1590/0103-8478cr20150370

GIOMETTI, F. H. C.; LEITE, L. G.; TAVARES, F. M.; SCHMIT, F. S.; BATISTA FILHO, F.; DELL'ACQUA, R. Virulência de nematoides entomopatogênicos (Nematoda: Rhabditida) a Sphenophorus levis (Coleoptera). Bragantia, Campinas, v. 70, n. 1, p. 81-86, 2011. DOI: $10.1590 /$ S0006-87052011000100013

KAYA, H. K.; BEDDING, R. A.; AKHURST, R. J. An overview of insect-parasitic and entomopatogenic nematodes. In: BEDDING, R. A.; AKHURST, R. J.; KAYA, H. K. Nematodes and the biological control of insect pests. East Melbourn: CSIRO Publications, 1993. p. $1-10$

KOPPENHÖFER, A. M.; COWLES, R. S.; COWLES, E. A.; FUZY, E. M.; KAYA, H. K. Effect of neonicotinoid synergists on entomopathogenic nematode fitness. Entomologia Experimentalis et Applicata, Wageningen, v. 106, n. 1, p. $7-18,2003$. DOI: 10.1046/j.15707458.2003.00008.x

KOPPENHÖFER, A. M.; KAYA, H. K. Synergism of imidacloprid and an entomopathogenic nematode: a novel approach to grub (Coleoptera: Scarabaeidae) control in turfgrass. Journal of Economic Entomology, Oxford, v. 91, n. 3, p. 618-633, 1998. DOI: 10.1093/ jee/91.3.618

LAWRENCE, J. L.; HOY, C. W.; GREWAL, P. S. Spatial and temporal distribution of endemic entomopathogenic nematodes in a heterogeneous vegetable production landscape. Biological Control, Amsterdã, v. 37, n. 3, p. 247-255, 2006. DOI: 10.1016/j.biocontrol.2006.02.002

MAHMOUD, F. Combining the botanical insecticides NSK extract, neemazal t $5 \%$, neemix $4.5 \%$ and the entomopathogenic nematode Steinernema feltiae cross $\mathrm{N} 33$ to control the peach fruit fly, Bactrocera zonata (Saunders). Plant Protection Science, Praga, v. 43, n. 1, p. 19-25, 2007.

MANACHINI, B.; SCHILLACI, D.; ARIZZA, V. Biological responses of Rhynchophorus ferrugineus (Coleoptera: Curculionidae) to Steinernema carpocapsae
(Nematoda: Steinernematidae). Journal of Economic Entomology, Oxford, v. 4, n. 106, p. 1582-1589, 2013. DOI: $10.1603 / \mathrm{EC} 13031$

MOLINA, J. P.; LÓPEZ, N. J. C. Producción in vivo de tres entomonematodos con dos sistemas de infección en dos hospedantes. Revista Colombiana de Entomología, Bogotá, v. 27, n. 2, p. 73-78, 2001.

NGUYEN, K. B.; HUNT, D. J. Entomopathogenic nematodes: systematics, phylogeny and bacterial symbionts. Nematology monographs and perspectives. Boston: CAB, 2007. 816 p.

PAVÃO, A. R.; FERREIRA FILHO, J. B. de S. Impactos econômicos da introdução do milho Bt11 no Brasil: uma abordagem de equilíbrio geral inter-regional. Revista de Economia e Sociologia Rural, Brasília, v. 49, n. 1, p. 81108, 2011. DOI: $10.1590 / \mathrm{S} 0103-20032011000100004$

PETERS, A.; POULLOT, D. Side effects of surfactants and pesticides on entomopathogenic nematodes assessed using advanced IOBC guidelines. IOBC/WPRS Bulletin, Ponte de Lima, v. 27, n. 6, p. 67-72, 2004.

POTRICH, T. D.; LORINI, I.; VOSS, M.; STEFFENS, M. C. S.; PAVANI, D. P. Metodologia de criação de Tenebrio molitor em laboratório para obtenção de larvas. Passo Fundo: EMBRAPA Trigo, 2007. 35 p. (Documentos online, 82).

SABINO, P. H. S.; MOINO JUNIOR, A.; ANDALÓ, V. Effects of some insecticides on the neutral lipid percentage, survival and infectivity of Steinernema carpocapsae ALL and Heterorhabditis amazonensis JPM 4. Nematoda, Campos dos Goytacazes, v. 1, n. 1, p. 1-7, 2014. DOI: $10.4322 /$ nematoda.02014.

TAVARES, F. M.; BATISTA FILHO, A.; LEITE, L. G.; ALMEIDA, L. C.; GOULART, T. M. Efeito sinérgico de combinações entre nematoides entomopatogênicos (Nemata: Rhabditida) e inseticidas químicos na mortalidade de Sphenophorus levis (Vaurie) (Coleoptera: Curculinidae). BioAssay, Piracicaba, v. 4, n. 7, p. 1-10, 2009. DOI: 10.14295/BA.v4.0.31

UNITED STATE DEPARTMENT OF AGRICULTURE - USDA. National Agriculture Statistics Service. Corn for grain yield: Charts maps. United States: USDA, 2019. Available at: https://www. nass.usda.gov/ Charts_and_Maps/Field_Crops/index. php. Access at: 10 jan. 2019.

VAINIO, A. Guideline for laboratory testing of the side-effects of pesticides on entomophagous nematodes Steinernema spp. IOBC/WPRS Bulletin, v. 15, n. 3, p. 145-147, 1992. 
VIANA, P. A. Lagarta-elasmo. In: SALVADORI, J. R.; ÁVILA, C. J.; SILVA, M. T. B. da. (Ed.). Pragas de solo no Brasil. Passo Fundo: EMBRAPA Trigo; Dourados: EMBRAPA Agropecuária Oeste; Cruz Alta: Fundacep Fecotrigo, 2004. p. 379-408.

VIANA, P. A.; MENDES, S. M. Lagarta-elasmo: importância econômica e danos. In: VIANA, P. A. Principais pragas subterrâneas do milho no Brasil. Sete
Lagoas: EMBRAPA Milho e Sorgo, 2011. p. 9-20. 63 p. ZORZETTI, J.; RICIETTO, A. P. S.; FAZION, F. A. P.; MENEGUIM, A. M.; NEVES, P. M. O. J.; VILASBÔAS, G. T. Isolation and characterization of Bacillus thuringiensis strains active against Elasmopalpus lignosellus (Zeller, 1848) (Lepidoptera, Pyralidae). Acta Scientiarum. Agronomy, Maringá, v. 39, n. 4, p. 417-425, 2017. DOI: 10.4025 /actasciagron.v39i4.32707 
